\title{
EFFECTS OF THE PRECIPITATION PATTERN AND VEGETATION COVERAGE VARIATION ON THE SURFACE RUNOFF CHARACTERISTICS IN THE EASTERN TAIHANG MOUNTAIN
}

\author{
YUAN, Z. ${ }^{1 *}-$ YAN, D. H. ${ }^{2}-$ XU, J. J. ${ }^{1}-$ WANG, Y. Q. ${ }^{1}-$ YAO, L. Q. ${ }^{1}-$ YU, Z. Q. ${ }^{1}$ \\ ${ }^{1}$ Changjiang River Scientific Research Institute, Changjiang Water Resources Commission of \\ the Ministry of Water Resources of China, \#23 Huangpu Road, Wuhan, Hubei, China \\ (phone: +86-137-1656-5927; fax: +86-027-8282-9732) \\ ${ }^{2}$ State Key Laboratory of Simulation and Regulation of Water Cycle in River Basin, China \\ Institute of Water Resources and Hydropower Research, \#1, Fuxing Road, Haidian District, \\ Beijing, China \\ *Corresponding author \\ e-mail: yuanzhe@126.com; phone: +86-137-1656-5927; fax: +86-027-8282-9732
}

(Received $11^{\text {th }}$ Jan 2019; accepted $8^{\text {th }}$ Mar 2019)

\begin{abstract}
Water is a kind of important component in natural environment, while the ecological construction can influence the hydrological regime. A successful ecology construction is based on effective recognition of the relationship between the regional vegetation and surface water resources. This work used several datasets, including meteorological data, remote sensing data and hydrologic data. The objective of this work is to identify the effects of the precipitation and the ecological succession of vegetation on the surface runoff. The results indicated that: (1) the precipitation and surface runoff reduced by $4.8-7.3 \%$ and $20.6-43.2 \%$ during $1961-1985$ and $1986-2011$, respectively. The reduction of the surface runoff was higher than that of the precipitation; (2) the natural surface runoff of the Taihang Mountain is positively correlated with the precipitation and negatively correlated with NDVI. The natural surface runoff would increase by 16.6-66.7\% with the hypothesis that vegetation during 1986-2011 was the same with that during 1961-1985; (3) considering the regional climate conditions, drought-tolerant native species should be chosen in landscape engineering of the Taihang Mountain. This effort can avoid exhaustion of water resource caused by the excessive construction of ecological project.
\end{abstract}

Keywords: precipitation, NDVI, surface runoff, attribution assessment

\section{Introduction}

Forest cover plays an important role in regulating land hydrological cycle, especially in precipitation redistribution, the impact of soil moisture movement and changing of runoff generation and confluence condition. Meanwhile, forest cover can reduce flood peak, increase runoff during dry season, control soil erosion and improve water quality. However, the relationship between forest and runoff has not reached a coincident conclusion. The main divergence is whether the forest cover will increase the soil moisture and decrease the runoff of the basin. There are two different views about this issue: the forest cover will increase the annual runoff for the retaining water capacity of forest, and the forest cover will increase precipitation and decrease ground surface evaporation. Hao, et al. (2004) did research in basin above Lushi hydrological station of the Luohe River, tributary of lower reaches of the Yellow River and the results indicated that the forest had increased the runoff. The annual runoff decreased obviously when most of the forest and grassland in the upper reaches of Mayinghe River Basin was turned into farmland (Wang et al., 2005). Because of the forest cover will increase evaporation and retain precipitation, enhance the use and exchange of deep 
phreatic water, accelerate the partial hydrological cycle and reduce surface runoff, many researches also demonstrated that the forest cover can reduce annual runoff. Similarly, the river runoff and flood peak can also be reduced. Zhou, et al. (2001) found that evapotranspiration will be the main factor of losing water when the basin is small. Therefore, the runoff will decrease if the forest cover increases.

Based on the data from more than 600 observation stations in the southern hemisphere, the runoff within ten years will decrease to a large degree after planting trees for carbon sequestration (Jackson et al., 2005). This phenomenon would lead to betrunking of the stream (Wang et al., 2006; Chen et al., 2009; Cao et al., 2009). After analyzing 94 basins around the world, Bosch, et al. (1982) found that the decrease of forest will result in the increase of runoff, while forestation in open field will cause the decrease of total runoff. Based on different methods, many other researches in different basins have reached the similar conclusion that the decrease of forest cover will lead to the increase of runoff (Siriwardena et al., 2006; Zhang and Schilling, 2006; Wang et al., 2008; Mao and Keith, 2009).

In addition, the annual runoff of the basin could be influenced by the forest vegetation change and the type of climatic region. For instance, the decrease of the forest cover rate would make the runoff coefficient markedly increase in the Loess Plateau. In arid and semi-arid areas, the evaporation capacity of forest is greater than the precipitation. The evaporation is the mainly moisture outlay of the ecosystem. Therefore, the forest coverage increase will result in the decrease of water yield of the drainage basin. Moreover, the variation of forest coverage exerts little effect on the annual runoff generation of the basin in the tropical and subtropical region. In the tropical and subtropical basin with abundant rainfall, the moisture evapotranspiration is depended on the climatic factor, and the vegetation coverage is not a key factor affecting the moisture evapotranspiration of the basin. The forest coverage variation had no significant influence on the runoff volume (Wang and Zhang, 2001). Currently, regional difference still exsits in the relationship between vegetation coverage and runoff. Therefore, taking into account the response of streamflow after vegetation change and precipitation becomes necessary.

In this study, we (1) investigated the relationship between precipitation and runoff depth, and the variation characteristics of NDVI in typical basin for analyzing vegetation effects on surface runoff; (2) compared the runoff generation and runoff coefficient variation as estimated using different calibration periods; and (3) examined the restoring computation of natural runoff based on the approach to estimate the characteristic of the precipitation and runoff and explored a general framework to incorporate the effects of precipitation and vegetation variation on runoff in typical basin.

\section{Materials and methods}

\section{Study area}

The Taihang Mountain is situated in a topographical transforming region. The North China Plain is in its eastward, and the Loess Plateau is in the west. This mountain is roughly parallel with the coast line of eastern China. In the summer time, the warm, moist air from the Pacific Ocean will be raised up to cause rainfall in the area where the elevation is higher than $800 \mathrm{~m}$. This is the reason why in the area where the elevation is higher than $800 \mathrm{~m}$ has a humid climate compared with places lower than $800 \mathrm{~m}$ in the 
Taihang Mountain. When the elevation is lower than $800 \mathrm{~m}$, the annual average temperature is around $12.3^{\circ} \mathrm{C}$, precipitation is around $500 \mathrm{~mm}$, and the annual potential evaporation is about $1700 \mathrm{~mm}$. Based on the special environmental characteristics, the ecology system are more fragile in this region. The eastern Taihang Mountain, situated between $112^{\circ} 7^{\prime} \mathrm{E}$ and $115^{\circ} 30^{\prime} \mathrm{E}$ and between $37^{\circ} 17^{\prime} \mathrm{N}$ and $41^{\circ} 15^{\prime} \mathrm{N}$, is the area investigated in this study, including the Yanghe River Basin, Yongdinghe Upriver Basin and Ziyahe Upriver Basin.

The daily precipitation data from 1961 to 2011 were gathered from the meteorological stations located in East Taihang Mountain Area (the stations close to the boundary were also included). Runoff data used in this research are collected from 3 typical hydrological stations of East Taihang Mountain. The representative hydrological stations are Xiangshuibao, Shixiali and Huangbizhuang reservoir, respectively (Table 1). Meanwhile, the actual measured streamflow data and natural streamflow data are available for the period of 1961-2011. The spatial distribution of 81 meteorological stations was screened in Figure 1.
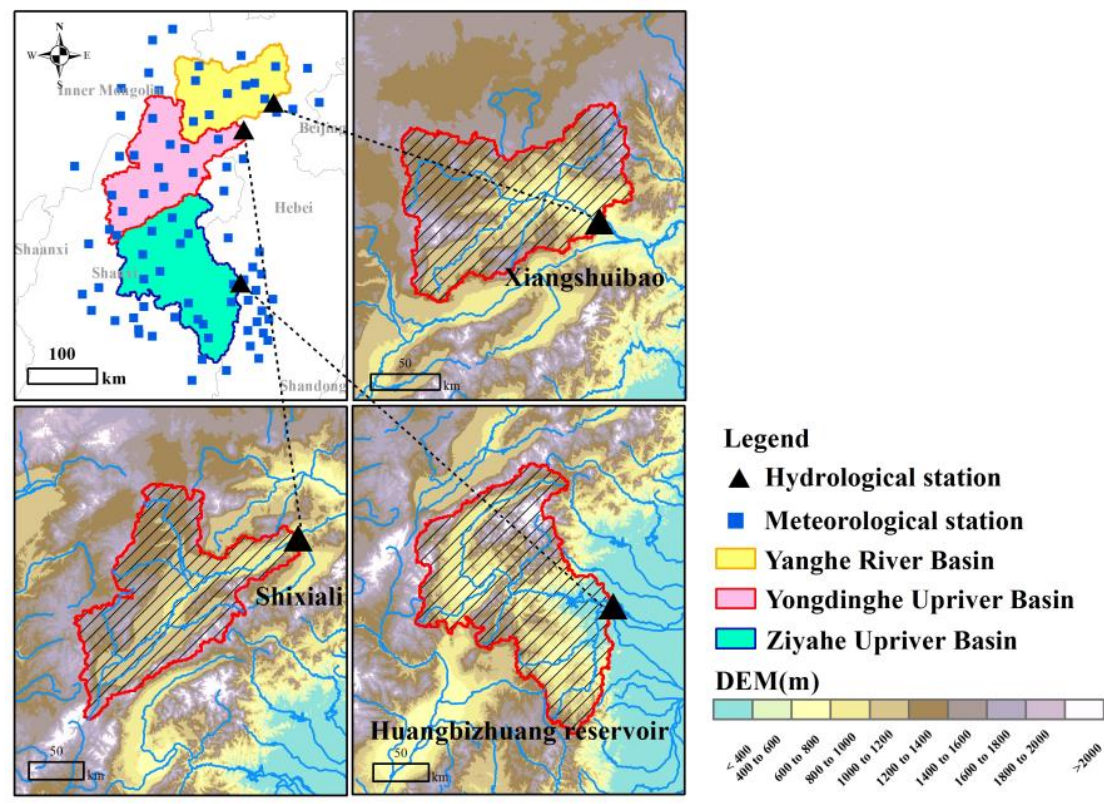

Figure 1. Locations of the paired catchments in Eastern Taihang Mountain

Table 1. Basic information of the 12 hydrological stations

\begin{tabular}{c|c|c|c|c}
\hline Hydrological station & Longitude & Latitude & Control area $\left.\mathbf{( k m}^{\mathbf{2}}\right)$ & River basin \\
\hline Xiangshuibao & $115^{\circ} 11^{\prime}$ & $40^{\circ} 31^{\prime}$ & 14507 & Yanghe River Basin \\
Shixiali & $114^{\circ} 33^{\prime}$ & $40^{\circ} 15^{\prime}$ & 23944 & Yongdinghe Upriver Basin \\
Huangbizhuang reservoir & $114^{\circ} 18^{\prime}$ & $38^{\circ} 15^{\prime}$ & 23272 & Ziyahe Upriver Basin \\
\hline
\end{tabular}

In this study, GIMMS NDVI data and MODIS NDVI data are selected. These two data sets are provided by the Godard Space Flight Center in the National Aeronautics and Space Administration (NASA). The GIMMS data is 15 day compound product with $8 \mathrm{~km}$ resolution in global scale. MODIS NDVI data is calculated from MODIS 
reflectance data based on the generalized algorithm. The preprocessing procedures include: quality assessment, region of interesting extraction, mosaicking and geometric rectification.

\section{Time trend analysis of NDVI}

According to the monthly NDVI data of the two datasets from 2000 to 2006, the monthly NDVI sequence (1982-2013) was derived through the per-pixel unary linear regression model. The per-pixel unary linear regression model can acquire the most appropriate regression equation for each pixel. The elementary structure form of the model for different data is calculated as Equations 1 and 2 (Ma, 2009).

$$
G_{i}=a+b V_{i}+\varepsilon_{i}
$$

where, parameter $a$ and $b$ are estimated by the least square method, and $\varepsilon_{i}$ is random error.

$$
b=\frac{\sum_{i=1}^{n}\left(G_{i}-\bar{V}\right) \times\left(G_{i}-\bar{G}\right)}{\sum_{i=1}^{n}\left(V_{i}-\bar{V}\right)} \quad a=\bar{G}-b \times \bar{V}
$$

where, $G_{\mathrm{i}}$ represents GIMMS NDVI in $i$ th month, and $V_{\mathrm{i}}$ is MODIS NDVI $(8 \mathrm{~km} \times 8 \mathrm{~km})$ in $i$ th month.,$G$ is the mean of all monthly GIMMS data from 2000 to 2009 at corresponding pixel.,$V$ is the mean of all monthly MODIS NDVI data $(8 \mathrm{~km} \times 8 \mathrm{~km})$ from 2000 to 2009 at corresponding pixel.

\section{Zonal statistics for precipitation and NDVI}

Since the meteorological stations are dense enough to capture the extent of East Taihang Mountain Area surface variation, the IDW (Inversed Distance Weighted) method is chosen to convert daily precipitation to grid surface data (Garcia et al., 2008). The spatial resolution of the interpolated areal daily precipitation is $5 \times 5 \mathrm{~km}^{2}$. Data processing was carried out in the ArcInfo Workstation 10.0. The relative calculation is conducted by ARC Macro Language (AML). The key codes of IDW are listed as follows:

IDW = idw (point_cover, spot_item, \#, 2, sample, 12, \#, \%cellsize\%, \%xmin\%, $\%$ ymin $\%, \%$ xmax \% , \% ymax \%)

where, the point_cover indicates the source of the data containing points with $\mathrm{z}$ values to be converted to a grid surface; spot_item is the item in the point coverage to be used as the $\mathrm{z}$ value for the interpolation; cellsize is the width or height of a cell, in map units. cellsize is set as 5000 in this study, which means the spatial resolution of the grid file is $10 \times 10 \mathrm{~km}^{2}$. $\{x \operatorname{xin}, y \min , x \max , y m a x\}$ represents the interpolation within the data processing, and xmin, ymin, xmax, ymax are 560000, 4000000, 915000, 4510000, respectively. 
According to the values of the enclosed grid cells, the mean value of annual precipitation and NDVI was calculated for each catchment. The code used in ZONALSTATS is shown as follows:

\section{outtable $=$ zonalstats $($ zonegrid, valuegrid, mean $)$}

where, the zonegrid represents the integer grid that identifies the zone for each cell, valuegrid is the floating grid that defines the annual precipitation and NDVI values of the cells, and mean is a keyword for zonal mean calculations. The computation process was conducted in the ArcInfo Workstation 10.0 platform.

\section{Determination of the streamflow decrease}

The statistic model of precipitation $\left(X_{1}\right)$, NDVI $\left(X_{2}\right)$ and runoff $(Y)$ was developed by the regression analysis method (Table 2). Then the responding relationship of precipitation, NDVI and runoff was analyzed through this statistic model.

Table 2. The responding relationship of precipitation, NDVI and annual runoff depth

\begin{tabular}{c|c|c}
\hline Item & Factor & Variable \\
\hline Dependent variable & Annual runoff depth & $Y$ \\
\hline \multirow{2}{*}{ Independent variable } & Annual precipitation & $X_{1}$ \\
& NDVI & $X_{2}$ \\
\hline
\end{tabular}

According to the starting time of the landscape engineering in Taihang Mountain, the time sequence of this work is divided into two periods: natural period (1961-1985) and impacted period (1986-2011). The vegetation coverage remained natural during the natural period. However, the vegetation has gained relative recovery in the impacted period, and the relationship between the precipitation and streamflow was changed in a certain extent. After the break point, $R_{\text {nature }}$ is indicated the average natural runoff (Fig. 2). Meanwhile, during the impacted period, the simulated natural runoff volume

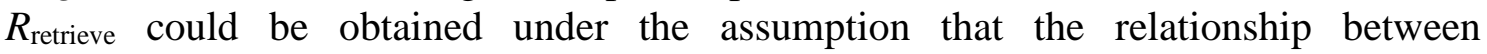
precipitation and streamflow was the same as that in the natural period. Thus, decrement runoff volume caused by the vegetation recovery after 1985 can be derived from the function as Equation 3.

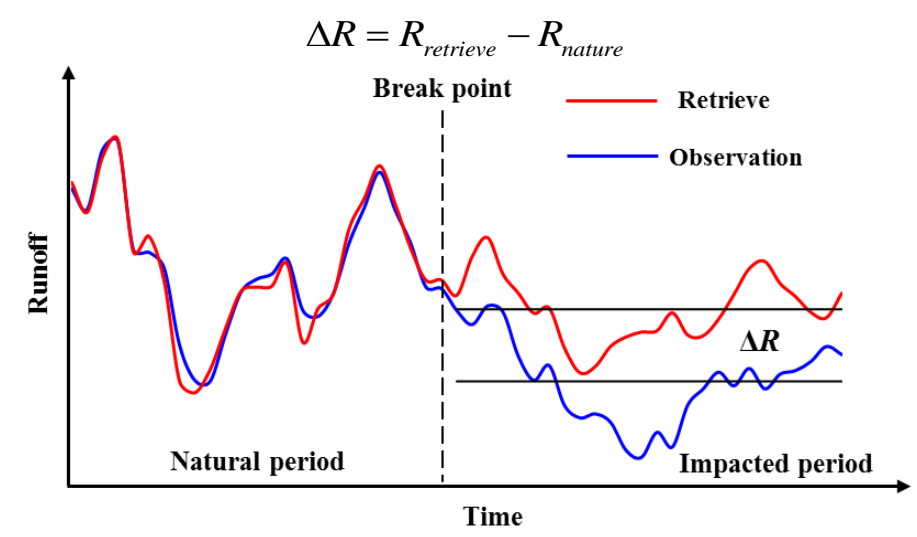

Figure 2. The framework for quantitative assessment of streamflow decrease 


\section{Results}

\section{The relationship between precipitation and runoff depth}

During 1961-2011, the annual precipitation within the Yanghe River Basin, Yongdinghe Upriver Basin and Ziyahe Upriver Basin showed a decreasing tendency, and the changing rate of annual precipitation were $-8.6 \mathrm{~mm} / 10 \mathrm{a},-8.0 \mathrm{~mm} / 10 \mathrm{a}$ and $15.3 \mathrm{~mm} / 10 \mathrm{a}$, respectively. Compared with the period 1961-1985, the average annual precipitation of three catchments reduced by 5.1\%, 4.8\% and 7.3\% during 1986-2011. The runoff and precipitation variation showed a similarity in the decreasing tendency. The variation rate of natural runoff of Yanghe River Basin, Yongdinghe Upriver Basin and Ziyahe Upriver Basin were $-5.9 \mathrm{~mm} / 10 \mathrm{a},-3.9 / 10 \mathrm{a}$ and $-9.9 \mathrm{~mm} / 10 \mathrm{a}$, respectively. The results demonstrated that the actual measured runoff depth decreased obviously within the study periods. The changing rates of actual measured runoff depth in the three typical basins were $-7.2 \mathrm{~mm} / 10 \mathrm{a},-6.5 \mathrm{~mm} / 10 \mathrm{a}$ and $-16.1 \mathrm{~mm} / 10 \mathrm{a}$, respectively. After 1985, the natural runoff depth reduced by $43.2 \%, 30.7 \%$ and $20.6 \%$ compared with the average runoff depth during 1961-1985. Similarly, the actual measured runoff depths were $66.8 \%, 76.1 \%$ and $54.3 \%$ lesser than the average value before 1985 . The difference between natural runoff and actual measured runoff is obvious under the pressure of anthropologic influence and it would be more obviously in the future (Fig. 3).

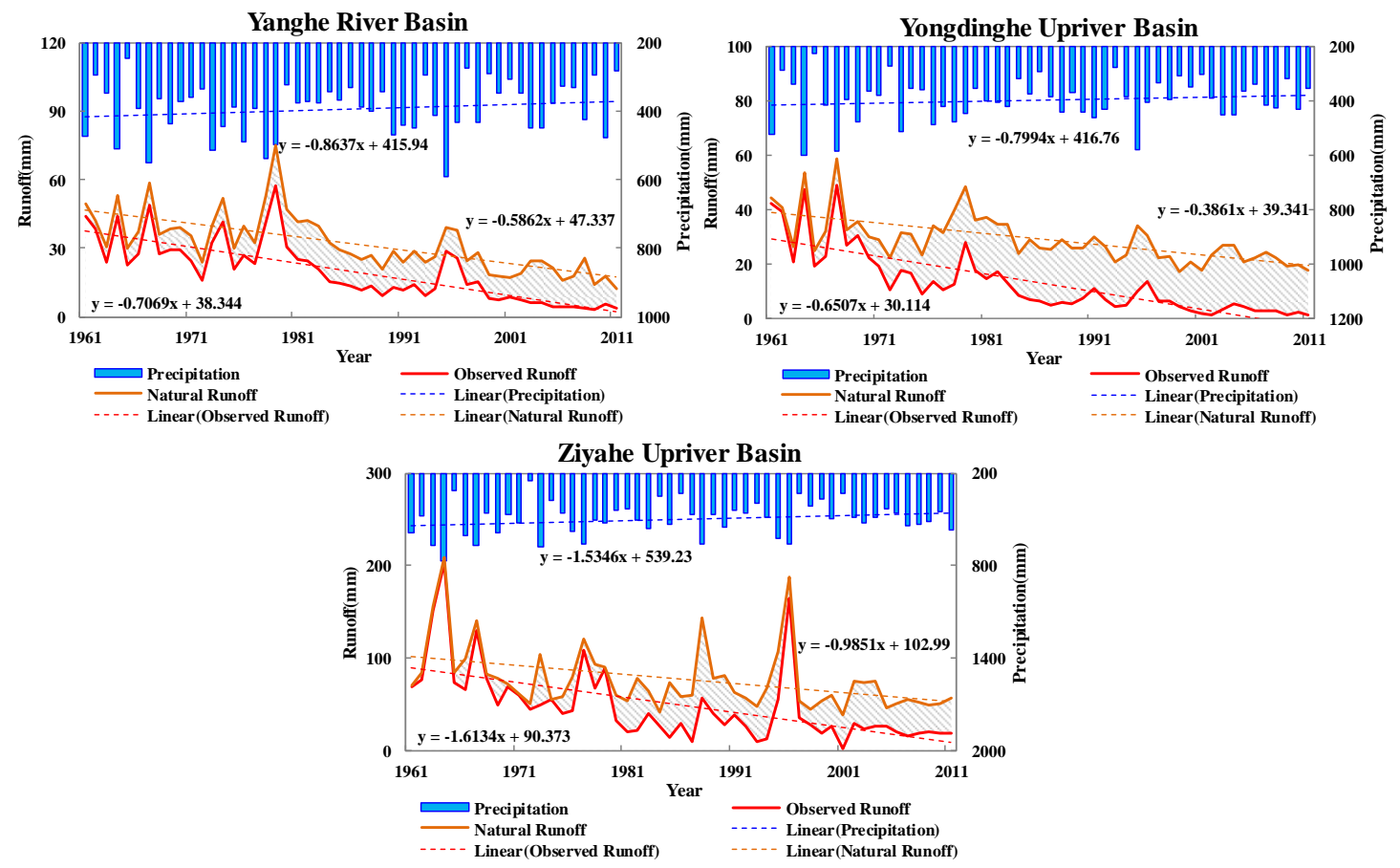

Figure 3. The annual precipitation and runoff depth variation in 1961-2011

The ratio of annual average intensive precipitation $(\mathrm{S}>25 \mathrm{~mm} / \mathrm{d})$ was gradually increasing from north area to south area. The probability of intensive precipitation in Yanghe River Basin, Yongdinghe Upriver Basin and Ziyahe Upriver Basin were 13.4\%, $15.0 \%$ and $23.0 \%$, respectively. The intensive precipitation ratio in the Yanghe River Basin and Yongdinghe Upriver Basin presented decreasing tendency during the 1961- 
2011 (Fig. 4). However, this ratio in Ziyahe Upriver Basin had an increasing tendency during the study period. Specially, the variation of intensive precipitation was obviously in the Yongdinghe Upriver Basin and Ziyahe Upriver Basin. With respect to the average intensive precipitation before 1985, the intensive precipitation ratio has reduced by 9.9\% in the Yongdinghe Upriver Basin. Moreover, the intensive precipitation ratio has increased by $3.6 \%$ in the Ziyahe Upriver Basin.
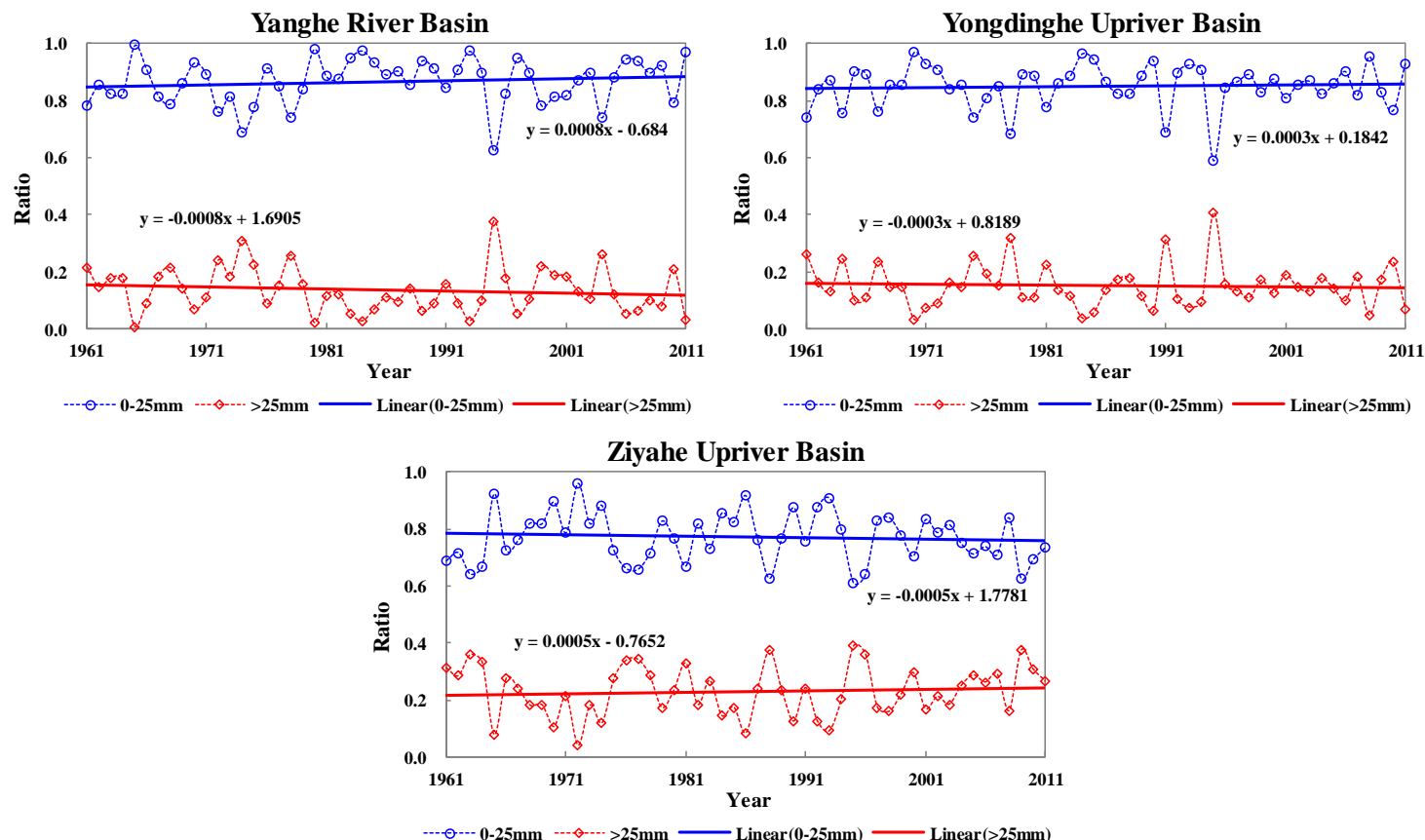

Figure 4. The probability of different intensive precipitation during 1961-2011

\section{Characteristics of NDVI variation in typical basin}

The NDVI of the Yanghe River Basin, Yongdinghe Upriver Basin and Ziyahe Upriver Basin presented an increasing tendency during 1983-2013 (Fig. 5), and their variation tendency rates were $0.017 / 10 \mathrm{a}, 0.015 / 10 \mathrm{a}$ and $0.009 / 10 \mathrm{a}$, respectively. The results demonstrated that the increased range of NDVI value in the north region was obviously higher than that in the south region (Fig. 6). The variation tendency ratio of NDVI in the north area was generally above 0.010/10a. The large-scale vegetation recovery was mainly benefited by the landscape engineering in Taihang Mountain. The vegetation recovery project built 1.36 million hectares of forest from 1986 to 2000. As in the second stage (2001-2010), the recovery project built 1.78 million hectares of forest. During the third stage (2011-2050), the project aims to build 0.42 million hectares of forest. The forest cover rate will be enhanced from $15 \%$ to $35 \%$ after this project completed. 

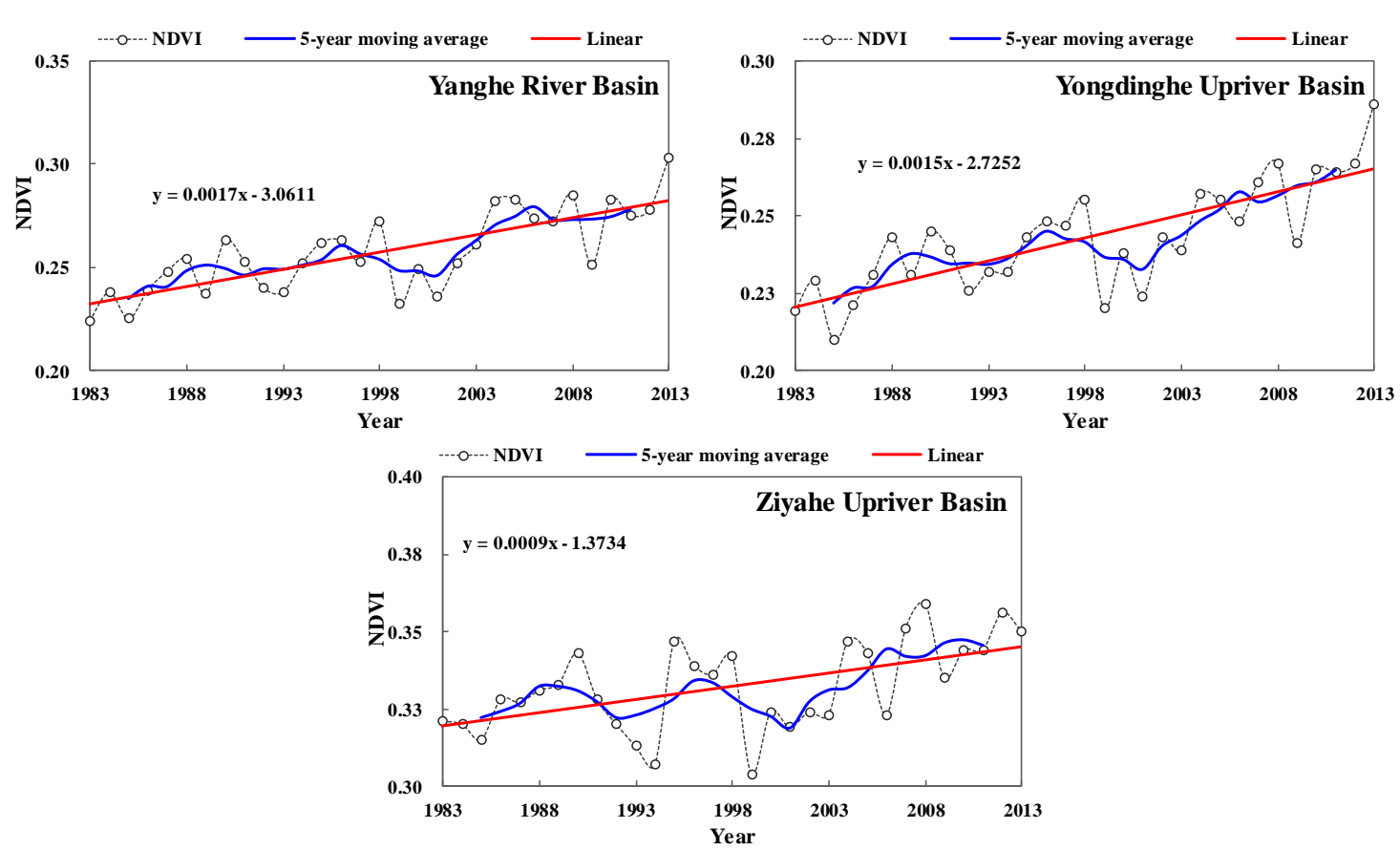

Figure 5. The variation of NDVI from 1983 to 2013

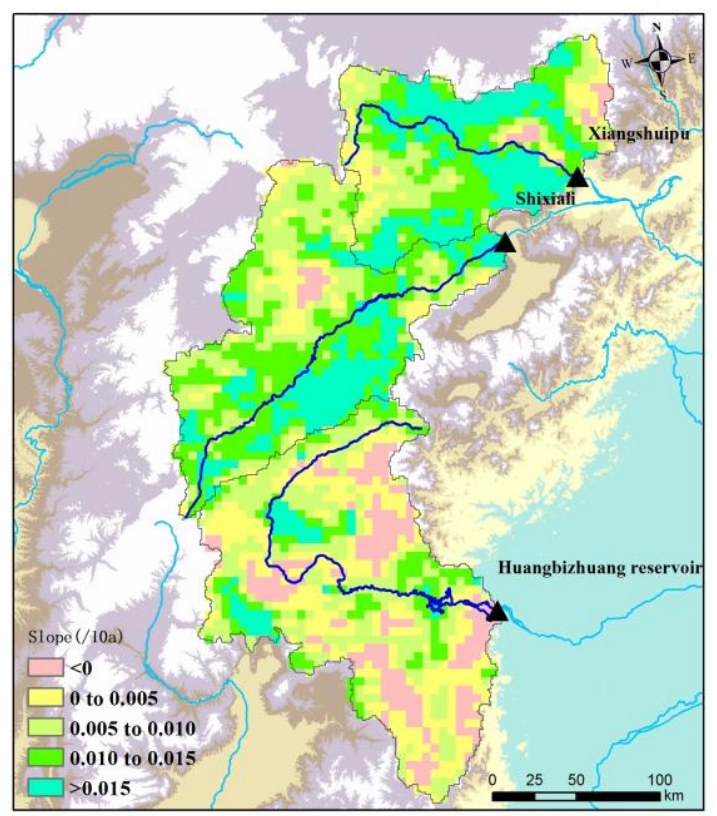

Figure 6. The variation tendency ratio of NDVI

\section{Evidence for runoff generation and runoff coefficient variation}

The runoff generation coefficient and runoff coefficient decreased obviously from 1961 to 2011. During the period, the runoff generation coefficients of Yanghe River Basin, Yongdinghe Upriver Basin and Ziyahe Upriver Basin reduced by $-0.014 / 10 \mathrm{a}$,$0.009 / 10 \mathrm{a}$ and $-0.015 / 10 \mathrm{a}$, and the runoff coefficient in the typical basins were $0.017 / 10 \mathrm{a},-0.016 / 10 \mathrm{a}$ and $-0.029 / 10 \mathrm{a}$, respectively. The results indicated that the runoff 
coefficient has more significant decreasing tendency since 1985 (Fig. 7). The average runoff generation coefficients in the Yanghe River Basin, Yongdinghe Upriver Basin and Ziyahe Upriver Basin were 0.10, 0.09 and 0.17 from 1961 to 1985. And the runoff coefficients in the typical basins were $0.07,0.05$ and 0.13 , respectively. However, during 1986-2011, the average runoff generation coefficients/runoff coefficients were $0.06 / 0.03,0.06 / 0.01$ and $0.14 / 0.06$, respectively. Meanwhile, the average runoff generation coefficients/runoff coefficients of the three typical basins have reduced by $40.1 \% / 64.0 \%, 27.2 \% / 74.9 \%$ and $14.3 \% / 50.7 \%$ compared to the average value during 1961-1985 (Fig. 8). The runoff generation coefficient and runoff coefficient decreased obviously in the northern region.
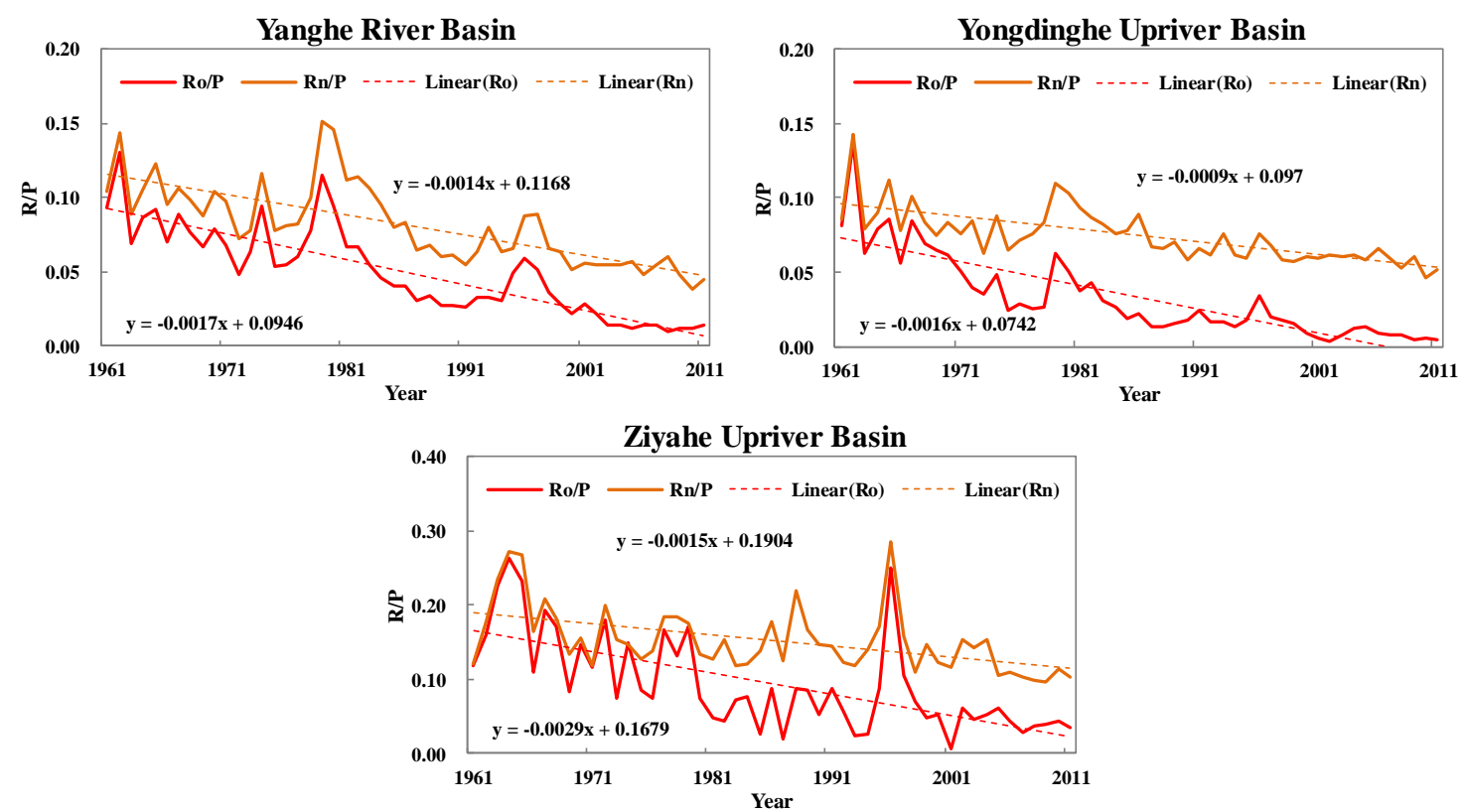

Figure 7. The interannual variation of runoff generation coefficient and runoff coefficient
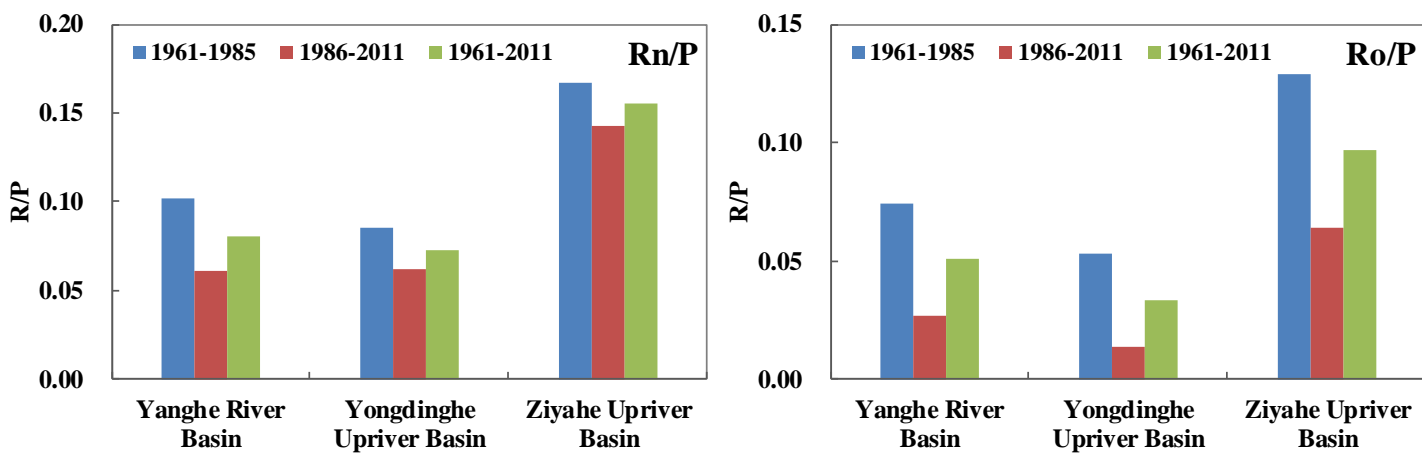

Figure 8. Different periods of runoff generation coefficient and runoff coefficient in typical basins

The least square method was carried out to conduct the regression analysis of precipitation $\left(X_{1}\right)$, NDVI $\left(X_{2}\right)$ and natural runoff depth $(Y)$. The regression analysis results demonstrated that the volume of runoff has positive relationship with the 
precipitation, and the NDVI has negative relationship with to the volume of runoff (Table 3). In conclusion, the vegetation in the eastern Taihang Mountain had greatly recovered due to the implement of landscape engineering. However, the forest covered area has unreasonable increased due to the excessive construction of vegetation. Thus, the volume of runoff in the typical basins was decreased to a certain degree for the influence of evapotranspiration increase.

Table 3. Regression analysis of precipitation, NDVI and natural runoff

\begin{tabular}{c|c|c}
\hline River basin & Regression equation & R2 \\
\hline Yanghe River Basin & $Y=0.07 X_{1}-198.59 X_{2}+47.93$ & 0.55 \\
Yongdinghe Upriver Basin & $Y=0.06 X_{1}-148.50 X_{2}+37.77$ & 0.68 \\
Ziyahe Upriver Basin & $Y=0.27 X_{1}-308.13 X_{2}+40.47$ & 0.55 \\
\hline
\end{tabular}

\section{Restoring computation of natural runoff}

Compared with the period of 1961-1985, the precipitation in the typical basins had reduced by $4.8-7.3 \%$ during 1986-2011. Nevertheless, the volume of natural runoff has reduced by $27.2-40.1 \%$ (Table 4 ). The decreased runoff volume was greater than the amount of precipitation in the typical basins. Specifically, the reduction amplitude of runoff generation coefficient was 14.3-40.1\%. Moreover, the reduction amplitude was increasing from south to north region, especially in the Yanghe River Basin. The relationship of precipitation and natural runoff in the typical basins are assumed to be similar with that during1961-1985, and the precipitation still remained the level during1986-2011. On this condition, the annual natural runoff depths of the Yanghe River Basin, Yongdinghe Upriver Basin and Ziyahe Upriver Basin were $39.0 \mathrm{~mm}$, $33.1 \mathrm{~mm}$ and $80.1 \mathrm{~mm}$. At the same time, the results demonstrated that the annual natural runoff depths within the typical basins has increased by $66.7 \%, 37.3 \%$ and $16.6 \%$ compared with that in the practical condition.

Table 4. Changes of annual mean precipitation and streamflow during the two periods in Yanghe River Basin, Yongdinghe Upriver Basin and Ziyahe Upriver Basin

\begin{tabular}{c|c|c|c|c|c}
\hline River basin & Period & $\mathrm{R} / \mathrm{P}$ & $\mathbf{P}_{\text {mean }} / \mathbf{m m}$ & $\mathbf{R}_{\mathbf{m e a n}} / \mathbf{m m}$ & $\mathbf{R}_{\text {retrieve }} / \mathbf{m m}$ \\
\hline \multirow{3}{*}{ Yanghe River Basin } & $1961-1985$ & 0.10 & 404.1 & 41.2 & \\
& $1986-2011$ & 0.06 & 383.3 & $\mathbf{2 3 . 4}$ & $\mathbf{3 9 . 0}$ \\
& Change & $-40.1 \%$ & $-5.1 \%$ & $-43.2 \%$ & \\
\hline \multirow{3}{*}{ Yongdinghe Upriver Basin } & $1961-1985$ & 0.09 & 405.9 & 34.7 & \\
& $1986-2011$ & 0.06 & 386.4 & $\mathbf{2 4 . 1}$ & $\mathbf{3 3 . 1}$ \\
& Change & $-27.2 \%$ & $-4.8 \%$ & $-30.7 \%$ & \\
\hline \multirow{2}{*}{ Ziyahe Upriver Basin } & $1961-1985$ & 0.17 & 518.7 & 86.4 & \\
& $1986-2011$ & 0.14 & 480.7 & $\mathbf{6 8 . 7}$ & $\mathbf{8 0 . 1}$ \\
& Change & $-14.3 \%$ & $-7.3 \%$ & $-20.6 \%$ & \\
\hline
\end{tabular}

\section{Conclusion}

In the recent 50 years, the annual precipitation in the eastern Taihang Mountain presented the decreasing tendency. In the Yanghe River Basin, Yongdinghe Upriver 
Basin and Ziyahe Upriver, the annual precipitation of the typical basins has reduced by $5.1 \%, 4.8 \%$ and $7.3 \%$, respectively. The volume of the natural surface runoff has larger decrease compared with that of precipitation. On the basis of the Taihang Mountains afforestation project, the vegetation coverage was greatly recovered. The variation tendency rate of the regional averaged NDVI was 0.009 0.017/10a. The increase of the forest coverage can enhance the evapotranspiration of the surface, which is one of the major reasons for the runoff decrease. Similarly, the relationship of precipitation and natural runoff in the typical basins are assumed to be similar with those during19611985, and the vegetation coverage remained the level before 1985. On this condition, the annual natural runoff depths of the Yanghe River Basin, Yongdinghe Upriver Basin and Ziyahe Upriver Basin were $39.0 \mathrm{~mm}, 33.1 \mathrm{~mm}$ and $80.1 \mathrm{~mm}$. At the same time, the results demonstrated that the annual natural runoff depths within the typical basins increased by $66.7 \%, 37.3 \%$ and $16.6 \%$ compared with that during the practical condition. Thus, the vegetation's restoration causes the regional runoff's decrease by 16.6 66.7\%.

The precipitation may continue decreasing in the future due to climate change and global warming. However, the surface evapotranspiration will be greatly enhanced for the continuous increasing temperature in this region. For this reason, the Taihang Mountain region may face the water shortage crisis in the future. Because of the water shortage tends to exist in long-term, how to balance water usage and vegetation restoration under the water shortage condition is becoming a challenge. In the future work, the selected vegetation species for afforestation project should consume less water and have a higher tolerance for water shortage condition. Furthermore, because of the water restrictions, the planted vegetation should keep lower densities to reduce water consume.

This research has adopted statistical methods to identify the impact of precipitation and vegetation variation on surface runoff. The formation of surface runoff is not only affected by precipitation and vegetation, but also by many other factors such as soil and temperature. Further research may use physically-based watershed eco-hydrological model to do more refined simulation of the eco-hydrological process, thus identifying the spatial difference of the impact of precipitation and vegetation variation on surface runoff. In the meantime, multi-set of vegetation restoration and repair scheme can be set. Optimal scheme which is the most suitable for the eastern Taihang Mountain can be selected.

Acknowledgements. This research was funded by [National Key Research and Development Project] grant number [2017YFC1502404]; [National Natural Science Foundation of China] grant number [51709008,51779013]; National Public Research Institutes for Basic R\&D Operating Expenses Special Project (no. CKSF2017029 and no. CKSF2017061/SZ).

\section{REFERENCES}

[1] Bosch, J. M., Hewlett, J. D. (1982): A review of catchment experiments to determine the effect of vegetation changes on water yield and evapotranspiration. - Journal of Hydrology 55(1): 3-23.

[2] Cao, W. Z., Bowden, W. B., Davie, T. et al. (2009): Modelling impacts of land cover change on critical water resources in the Motueka river catchment, New Zealand. - Water Resources Management 23(1): 137-151. 
[3] Chen, Y., Xu, Y., Yin, Y. (2009): Simulation of the hydrologic response to land-use and land-cover changes scenarios: a case study of Xitiaoxi Basin. - Journal of Natural Resources 24(2): 351-357.

[4] Hao, F., Chen, L., Liu, C., Dai, D. (2004): Impact of land use change on runoff and sediment yield. - Journal of Soil and Water Conservation 18(3): 5-8.

[5] Jackson, R., B., Jobbagy, E. G., Avissar, R. et al. (2005): Trading water for carbon with biological carbon sequestration. - Science 310: 1944-1947.

[6] Ma, M. G. (2009): Research of Monitoring and Simulation of Vegetation Dynamics in Northwest China, Based on Time Series Data. - Academic Exchanges of Young Scholars in the Field of Geo-Information Science and Technology, Beijing.

[7] Mao, D., Keith, A. C. (2009): Impacts of land-use change on hydrologic responses in the Great Lakes region. - Journal of Hydrology 374(1-2): 71-82.

[8] Siriwardena, L., Finlayson, B. L., Mcmahon, T. A. (2006): The impact of land use change on catchment hydrology in large catchments: the Comet River, Central Queensland, Australia. - Journal of Hydrology 326(1-4): 199-214.

[9] Wang, L. X., Zhang, Z. Q. (2001): Impacts of forest vegetation on watershed runoff in dryland areas. - Journal of Natural Resources 16(5): 439-444.

[10] Wang, S., Zhang, Z., Sun, G., Zhang, M., Yu, X. (2006): Effects of land use change on hydrological dynamics at watershed scale in the Loess Plateau. A case study in Lvergou watershed, Gansu Province. - Journal of Beijing Forestry University 28(1): 48-54.

[11] Wang, S. F., Kang, S. Z., Zhang, L. et al. (2008): Modelling hydrological response to different land-use and climate change scenarios in the Zamu River basin of northwest China. - Hydrological Processes 22(14): 2502-2510.

[12] Wang, G., Zhang, Y., Liu, G. et al. (2005): Effects of land use change on stream flow in Mayinghe River Basin during 1967-2000. - Science in China D: Earth Science 35(7): 671-681.

[13] Zhou, X., Zhao, H., Sun, H. (2001): Proper assessment for forest hydrological effect. Journal of Natural Resources 16(5): 420-426.

[14] Zhang, Y. K., Schilling, K. E. (2006): Increasing stream flow and base flow in Mississippi River since the 1940s: effect of land use change. - Journal of Hydrology 324(1-4): 412-422. 